CZU 321:351.86

DOI https://doi.org/10.52388/1812-2566.2021.3(94).02

\title{
THE STATE AND NATIONAL SECURITY: CURRENT ISSUES AND CONTEMPORARY APPLICATION
}

\author{
Ludmila OLEINIC \\ Doctor of Political Science, Associate Professor, \\ The American University of Moldova, Chisinau, Republic of Moldova, \\ Affiliate to George Mason University, Washington DC / Arlington, USA \\ e-mail: oleynyckliuda2@yahoo.com \\ https://orcid.org/0000-0002-5884-9563
}

The dominant security paradigm has styled the nation state in order to reflect its popular basis as the fundamental source of social belonging. The good governed nation state is a formidable security organization as an all. It is through the nation state that citizens guarantee their own security, individual as well as collective. Personal security thus becomes dependent upon and even analogous to national security. In contrast, insecurity is understood as an external threat located outside the state. Internally or externally directed, policies taken to ensure national security may be of an economic, political or military nature. National security measures thus include, among others: maintaining effective armed forces; implementing anti-terrorist measures; ensuring civil and emergency defenses; using intelligence to detect and counter external attack and internal subversion; using diplomacy to strengthen alliances and isolate threats; and using economic power to encourage cooperation and isolate or weaken political rivals. Generalizing, the article reflects the national security approaches, specifics and extreme circumstances of liberal democracies, authoritarian states and failed states.

Keywords: nation state, national security, security policy, international terrorism, liberal democracy, authoritarian state, failed state.

\section{STATUL ȘI SECURITATEA NAȚIONALĂ: PROBLEME CURENTE ȘI ABORDARE CONTEMPORANĂ}

Paradigma dominantă a securității a identificat statul națiune în vederea reflectării bazei comune ca sursă fundamental a sociumului. Un stat națiune bine guvernat reprezintă o organizare formidabilă a securității per general. Așa cum prin intermediul statului națiune cetățenii au asigurată propria securitate, atât individuală, cât și colectivă. Securitatea personală devenind dependentă și chiar identică cu securitatea națională. Din contra, insecuritatea este percepută ca o amenințare externă localizată în afara statului. Intern sau extern direcționată, politicile menite să asigure securitatea națională pot fi de natură economică, politică sau militară. Astfel, printre măsurile de securitate națională sunt: menținerea forțelor armate efective; implementarea măsurilor antiteroriste; asigurarea apărării civile și de urgență; utilizarea serviciilor secrete pentru detectarea sau contracararea atacurilor externe și diversiunilor interne; folosirea diplomației pentru consolidarea alianțelor și izolarea amenințării; utilizarea puterii economice pentru încurajarea cooperării și izolarea sau diminuarea influenței oponenților politici. Generalizând, prezentul articol reflectă abordările, particularitățile și circumstanțele extreme a securității naționale a democrațiilor liberale, statelor autoritare și statelor eșuate.

Cuvinte-cheie: stat națiune, securitate națională, politică de securitate, terorism internațional, democrație liberală, stat autoritar, stat eșuat. 


\section{ÉTAT ET SÉCURITÉ NATIONALE: PROBLÈMES ACTUELS ET APPROCHE CONTEMPORAINE}

Le paradigme dominant de la sécurité identifiait l'état-nation en vue de refléter la base commune comme source fondamentale de la société. Un état-nation bien gouverné est une organisation formelle de la sécurité en général. Tout comme à travers l'état-nation, les citoyens ont leur propre sécurité, à la fois individuellement et collectivement. La sécurité personnelle devient dépendante et même identique à la sécurité nationale. Au contraire, l'insécurité est perçue comme une menace extérieure située en dehors de l'état. Dirigées en interne ou en externe, les politiques visant à assurer la sécurité nationale peuvent être de nature économique, politique ou militaire. Ainsi, les mesures de sécurité nationale font partie, telles que: le maintien de forces armées efficaces; la mise en ouvre de mesures antiterroristes; assurer une défense civile et d'urgence; utiliser les services secrets pour détecter ou contrer les attaques externes et les détournements internes; utiliser la diplomatie pour renforcer les alliances et contenir la menace; et l'utilisation du pouvoir économique pour renforcer la coopération et isoler ou diminuer les opposants politiques. En généralisant, cet article reflète les approches, les particularités et les circonstances extrêmes de la sécurité nationale des démocraties libérales, des états autoritaires et des états en faillite.

Mots-clés: état-nation, sécurité nationale, politique de sécurité, terrorisme international, démocratie libérale, état autoritaire, état défaillant.

\section{ГОСУДАРСТВО И НАЦИОНАЛЬНАЯ БЕЗОПАСНОСТЬ: АКТУАЛЬНЫЕ ПРОБЛЕМЫ И СОВРЕМЕННЫЙ ПОДХОД}

Доминирующая парадигма безопасности определила наџиональное государство как общую базу и фундаментальный источник общества. Хорошо управляемое национальное государство представляет собой хорошую организацин безопасности в циелом. Особенно через нациинальное государство, граждане обеспечивают собственную безопасность, как индивидуальную, так и коллективную. Личная безопасность становится зависимой от национальной безопасности и даже тождественна ей. Напротив, незащчиченность воспринимается как внешняя угроза, находящаяся за пределами государства. Политика, изнутри или извне, направленна на обеспечение национальной безопасности, и может иметь экономический, политический или военный характер. Таким образом, меры национальной безопасности включают следующее: поддержание боеспособности вооруженньх сил; реализачия антитеррористических мер; обеспечение гражданской и чрезвычайной защчтыь; использование секретных служб для обнаружения или противодействия внешним атакам и внутренним диверсиям; использование дипломатии для укрепления союзов и изоляции угрозы; использование экономической мощи для поощрения сотрудничества и изоляциии или подавления политических оппонентов. В иелом, данная статья отражает подходы, особенности и крайние обстоятельства национальной безопасности либеральньх демократий, авторитарных государств и несостоявиихся государств.

Ключевые слова: национальное государство, наџиональная безопасность, политика безопасности, международньий терроризм, либеральная демократия, авторитарное государство, несостоявщееся государство.

\section{Introduction}

The idea of security identifies it as a core value of human life. To be secure is to be undisturbed by danger or fear. The desire for security is a defensive and self-protecting response to the fact or threat of harm from other human beings. If there were no threatening people, the need to guarantee security would disappear. The four key assumptions underlying the idea of security - security in (or of) what, from what, for what, and by what means - are each discussed and analyzed. In this article normative and instrumental methodological approaches to security are compared and contrasted. Being explored particularly the contradictions and dilemmas in the con- 
text of recent debate on the problem of intervention with reference to national security of the state. The originality of work consists in the analysis of different states promoted policy and their national security approaches.

Throughout the scientific research the author respected the historical and comparative methods used in order to emphasize the differences and discrepancies between mentioned phenomena and political actors on national and international stage.

\section{Nation states and national security}

As a result, from the time of the American and French revolutions onwards, the dominant security paradigm has viewed the state, now styled the nation state, to reflect its popular basis, as the fundamental source of social belonging and ergo also personal well-being. The nation state in the Western liberal tradition is understood as an extension of the will of the individual citizens who comprise it and thus becomes the supreme moral association within society. Its raison d'être is to preserve and promote just relations among the citizenry, thereby ensuring that they remain free and equal.

A well-governed nation state is a formidable security organization. It is for this reason that the nation state ultimately replaced clans, tribal societies, fiefdoms, free cities, medieval guilds, duchies, dynastic states and even empires, among others, to become the basic form of modern political organization. The nation state performs this central task by acting as an effective and impartial arbiter within society.

In all of this, it is crucial to remember that according to liberal political theory the state not only belongs to the nation but is in fact a creation of the nation. In other words, the state is not meant to be a remote entity separate from and imposing itself upon the nation. Far from it, it is through the nation state that citizens guarantee their own security, individual as well as collective. Personal security thus beco- mes dependent upon and even analogous to national security. In contrast, insecurity is understood as an external threat located outside the state/citizen relationship: therefore in theory (if not in fact) the state cannot pose a threat to its own citizens whose personal interests are synonymous with state interests. This ideal is captured by the Latin expression: $u b i$ bene, ibi patria: 'where it is well with me, there is my country'.

For the national security paradigm to hold true, the coercive power of the state should be used as a last resort and as rarely as possible. In other words, the state is legitimate only in so far as its coercive power 'affects most people marginally, negligibly, and indirectly, while its full might is meted out to a relatively small (and in principle) indefinite group of 'law-breakers'[1, P.53.].

That is the ideal, and in many states it closely corresponds to historical reality. We might even go so far as to say that the history of such countries in the period since 1945 bears out the liberal idea that a secure state is the ultimate foundation for the 'good life'. Citizens of such states - examples include the member states of the European Union, the United States, Canada, Australia, New Zealand and Japan, among others - enjoy the highest standards of living in the history of humankind. These are of course highly internationalized nation states, whose populations benefit greatly from common security arrangements (NATO, etc.) as well as economic unions (like the European Union and the North American Free Trade Association) and internationally institutionalized free trade (GATT, WTO), etc. This enviable condition owes much to the state's ability to create and maintain a secure society in which individual freedom is protected.

\section{National security as an arrangement}

The nation state defines the standard of acceptable conduct within which citizens can pursue 
their own ends free from outside interference. This is often presented as a reciprocal arrangement. To understand national security in this way draws our attention to the fact that the nation state, and specifically its agents and representatives, is given a monopoly on the use of force only insofar as it is necessary to protect against harmful intervention and punish those who violate the common legal framework.

In other words, the underlying rationale here is one of force used only for the public good and not for personal power or aggrandizement. Public officials are therefore responsible for providing both national security and personal security and they can be held to account for neglecting or failing to fulfil their security mandate. At the same time, citizens can be condemned for ignoring or violating any reasonable security demands placed upon them.

That reciprocal security obligation between the nation state and its citizens is the normative basis upon which the nation state's claim to be a protector of the people is often justified. From this perspective, the nation state is the provider of peace, order and - by implication - good governance. The term 'national security' has thus come to refer to all those public policies through which the nation state ensures its survival as a separate and sovereign community and, in so doing, the safety and prosperity of its citizens.

\section{National security policies}

Policies taken to ensure national security may be of an economic, political or military nature. And they may be either internally or externally directed. National security measures thus include, among others: maintaining effective armed forces; implementing anti-terrorist measures; ensuring civil and emergency defenses; using intelligence to detect and counter external attack and internal subversion; using diplomacy to strengthen alliances and isola- te threats; and using economic power to encourage cooperation and isolate or weaken political rivals. For example, the 2002 National Security Strategy of the United States of America singles out 'defending American Nation against its enemies' as the 'the first and fundamental commitment of the US Federal Government'. To do that, the US government says it will 'make use of every tool in its arsenal - military power, better homeland defences, law enforcement, intelligence, and vigorous efforts to cut off terrorist financing.' [2, p.1].

\section{National security and the war on terror}

In extreme circumstances (war or threat of war), even liberal democracies may restrict the civil liberties of resident aliens and sometimes also their own national citizens. We see evidence of such policies in the American response to the threat of international terrorism after 9/11. A 2003 report by the Washington-based Lawyers Committee for Human Rights documents post-September 11 restrictions in several key policy areas, including government openness, personal privacy, immigration and security-related detention [3, p.16].

Most notorious of these are perhaps the set of extra-legal institutions established by executive order to bypass the federal judiciary in cases relating to the 'war on terror'. In such circumstances, the nation state may single out certain individuals for security-related reasons. For example, the American Civil Liberties Union claims that security screening of immigrants and refugees since $9 / 11$ has disproportionately targeted males who fit a specific 'racial or ethnic profile' (i.e. of Arab origin) [4, p.28].

In other words, even where its function more or less corresponds with the liberal ideal, national security comes at a price. Citizens must pay for their security. They do that in their taxes, in their obligation to obey the law, in the requirement to perform military duty in times of war or threat of war, and 
in accepting certain incursions into their usual civil liberties when circumstances require it.

The price of security is not without its controversies. In a liberal democracy there will always be those who claim the price is too high because the perceived gain in national security does not justify the necessary infringement of individual freedom needed to sustain it. We see exactly this sort of argument at work in public criticism directed at post-9/11 anti-terrorist measures in the United States.

\section{National security in authoritarian states}

Outside Western liberal democracies, the potential incompatibility of national security and personal security is arguably even greater. In authoritarian or police states like the German Democratic Republic (communist 'East Germany') or the People's Republic of China (PRC) or the Democratic People's Republic of Korea (communist North Korea), security for the rulers may translate into profound insecurity for the ruled.

Communist rule in the German Democratic Republic was only sustained by the very real possibility of military intervention by the Red Army. The threat of such intervention effectively prevented any democratic opposition from arising. And it was only after the Brezhnev Doctrine (which made it an obligation of communist countries to intervene in support of communist rule elsewhere) was publicly repudiated by the Soviet Union in 1989 in favor of the so-called 'Sinatra Doctrine' (they do it their way) that communist rule in Eastern Europe came to an end.

The People's Republic of China (PRC) is another authoritarian state in which the Chinese Communist Party continues to rule by maintaining a tight grip on society. Chinese Communist Party members hold almost all top government, police and military positions. Continued rule of the Chinese Communist Party and its hierarchy relies on the control of public officials, the media and the security apparatus, and the continued improvement in the living standards of most of the country's citizens. In theory, the constitution guarantees an independent judiciary; but, in practice, the ruling Chinese Communist Party frequently intervenes in the judicial process, and even direct verdicts in many high-profile political cases. The net result of all this is that the Chinese people lack the freedom to express political opposition and the right to change their political leaders or form of government. Nowhere is this fact more powerfully revealed than in the brutal suppression of the Tiananmen Square demonstrations of 1989.

In a similar vein, the communist government of North Korea has long used rationing as a means to control its population. By banning people from buying and selling grain, it has forced them to rely on the state for their most basic needs. This policy has proven very effective at ensuring the political survival of Kim Jong-il and the Korean Worker's Party. But the price for their security has been a widespread famine and consequent suffering for the people of North Korea [5, p.34-39].

\section{Security in weak, failed or quasi-states}

Alternatively, in what are variously referred to as weak or failed or quasi-states, there is in effect no civil rule and instead circumstances closely approximate what Thomas Hobbes referred to as the 'state of nature' which is a 'war of all against all' in an unending struggle for survival. States are generally deemed 'successful' when they are able to maintain effective control over territory and population through a monopoly on the legitimate use of force - indeed, this was the classic, nineteenth-century definition of sovereignty. Conversely, when states cannot satisfy these basic criteria, their statehood becomes suspect. States may fail when rival actors such as warlords or popular militias usurp some of their governmental powers, in particular the monopoly of force. States are also said to fail in those circum- 
stances where they are rendered ineffective because of high crime rates, extreme corruption, a powerful 'black (unregulated) market', judicial ineffectiveness, military interference in politics, or in cultural situations where traditional leaders have more authority than the state in a certain area of competency or regional jurisdiction.

Domestic circumstances in the Democratic Republic of the Congo, Somalia, Sierra Leone and the Sudan have in recent years all been characterized by conditions of armed conflict, famine, disease and refugees. Consequently, these are widely acknowledged to be 'failed states.'

Significantly, these four are far from being isolated cases: according to the 2005 Failed States Index compiled by Foreign Policy and the Fund for Peace, 'about 2 billion people live in insecure states, with varying degrees of vulnerability to widespread civil conflict' $[6, p .7]$. In other words, for somewhere in the region of 2 billion men, women and children worldwide, national security has failed to guarantee personal security. This statistic is a very damning indictment of the national security paradigm. And it calls into question the very basis upon which security is understood in the liberal tradition - the nation state is a tremendous boon to personal security in some places, but in very many others it is tremendous liability.

\section{Conclusions}

Generalizing, can be affirmed that security was examined especially from the perspective of the state. As was revealed, the state had in its origins, a security arrangement and it remains so today. A well-governed nation state is a formidable security organization. It is for this reason that the nation state ultimately replaced clans, tribal societies, fiefdoms, free cities, medieval guilds, duchies, dynastic states and even empires, among others, becoming the basic form of modern political organization. The term 'national security' has thus come to refer to all those public policies through which the nation state ensures its survival as a separate and sovereign community and, in so doing, the safety and prosperity of its citizens. The reciprocal security obligation between the nation state and its citizens is the normative basis upon which the nation state's claim to be a protector of the people. For the national security paradigm to hold true, however, the coercive power of the state should be used as a last resort and as rarely as possible. But that is not always the case. Even in liberal democracies, what Barry Buzan terms a 'defense dilemma' may arise as the examples of nuclear deterrence and counter-terror measures make clear. The experience of totalitarian and weak, failed or quasistates also were recalled to demonstrate the limitations of the national security paradigm.

\section{References}

1. BERKI, R.N. Security and society. London: J.M. Dent and Sons, Sec. Ed, 1991. 198 p.

2. HERZ, J. The security dilemma in international relations: background and present problems, p. 21. www. whitehouse.gov/nsc/nssintro.html seen on August 29, 2021.

3. Lawyers Committee for Human Rights, 2003. 206 p. www.humanrightsfirst.org/pubs/descriptions/AssessingAssessingthe NewNormal.pdf

4. New York: American Civil Liberties Union, 2004, 151 p. www.aclu.org/Files/OpenFile.cfm?id=15101, seen on August 16, 2021.

5. JACKSON-PREECE, J. Security in international relations. Oxford, 2011.

6. KALDOR, M. American power: from „compellance" to cosmopolitanism. www.foreignpolicy.com/story/ cms.php?story_id=3098, seen on September 1, 2021. 